\title{
Simulacra in Women's Face Images: Reading Make Up Tutorial Phenomenon on Instagram
}

\author{
Desy Nurcahyanti ${ }^{1}$ dan Rini Maulina ${ }^{2}$ \\ \{desynurcahyanti@staff.uns.ac.id ${ }^{1}$, rini.maulina@email.unikom.ac.id² \\ ${ }^{1}$ Universitas Sebelas Maret, Surakarta, Indonesia \\ ${ }^{2}$ Universitas Komputer Indonesia, Bandung, Indonesia
}

\begin{abstract}
Facial aesthetics has long been a special concern in all ethnic groups in the world as women's desires and intuition. Global agreement has changed and reconstructed the perspective of beautiful image for women. Thus, diversity which contains the wisdom of traditional values on the definition of beautiful has become narrower and shallow. The purpose of this research is to find out and analyze the motivation of women in using Instagram as publications medium for makeup tutorial activities with various backgrounds. The research method used is an imagological perspective approach which places visual culture phenomenon as a false reality in the society. The data which possess relevance with or discuss about simulacra, women, phenomena, and Instagram were analyzed using documentation and archives. Furthermore, the results of data analysis and discussion show that women's weakness regarding complexion (skin) image is different from the general public conventions on beauty. In fact, natural appearance anomalies caused by hormonal conditions is frequently also considered as such a serious disorder as acne and oily skin. Visual illusion through make up may be considered as a conventional means which is able to distort the literal meaning of real beauty.
\end{abstract}

Keywords: visual culture, face image, Instagram, beauty, make up tutorial, simulacra

\section{INTRODUCTION}

Face is one of millions objects currently dominating Instagram's screen. Based on a survey of an independent company engaging in consumer satisfaction, Instagram users' electability has continuously increased since its launch 8 years ago than its acquiring company 2 years later, Facebook. Primary visual content feature rather than displaying long caption is considered more universal which make it aptly to obtain the meaning of signs and symbols [1]. Human intuition (instinct) to see shapes and colors is much more dominant than reading and observing letters sequence. In addition, most of users interested in this social media platform are female. Instagram visual power and easy mobility access give women more space to instantly interact and build dialogue. Women with skin image until now get an unlimited 
playing arena in actually a pro-contra area [2]. All of their commodity forms are ready-toconsume displayed and spreading a trap net for activists and supporters whose limited knowledge about propaganda. Such special and light (minor) zones as make up topic become commodities which are able to gain profits, commerciality and popularity. Furthermore, Instagram is a field for the growth of new profession which has been predicted since the beginning of social media existence, for instance: beauty influencers, autodidact make-up artists, endorsers, and celebgram (celebrities on Instagram) [3]. In addition, the positive side of this social media is definitely opening employment and creativity for tens of thousands or even millions of people on an international scale.

Hyper-reality condition on simulacra forms the building of reality models without any origin as work products in the form of culture [4]. Constitution of pseudo reality has affected most recent society who lives comfortably in cyberspace as netizens. The ease and variety of reconstruction are some facilities provided by social media, especially Instagram, without heavy physical losses rather than real visualization that require many equipments and expensive cost (high capital). It becomes interesting to question about simulacra when reading make up tutorials phenomenon which bring women to beauty world simulation; a well practiced visual culture theory [5]. Hyper-reality framework in this context is likely similar to that in science fiction films with only different scenario in complementary components as well as actors or the doers [6].

\section{METHOD}

Imagology perspective, a term popularized by Milan Kundera, a novelist on Immortality, is used as a method to place visual culture phenomenon of make up tutorials on Instagram as a pseudo or temporary condition possessing a significant impact as an image for the doer [7]. The data were obtained from Instagram page, as well as the limitation of research area, and they are narrowed based on the topics specifically discussing make up tutorial with a variety of personal motivations or demands for certain conditions. Data collection was based on the correlation between descriptions and analysis in discussion. Moreover, research methods for media studies and cultural studies were used to frame the discussion of the phenomenon [8]. Studies on related literature and previous researches were passively used to strengthen the analysis and research findings [9].

\section{RESULT AND DISCUSSION}

Kylie Jenner is a name which is very well-known in Instagram world. She has successfully summarized three keywords, i.e. viral, beauty influencer, and endorse. The first keyword shows her popularity level. It starts with contradictory and sensational reality show since it displays an unnatural daily life describing celebrity family communication and problems. The con is due to the fact that the family problem is merely caused by differences related to branded products background. The problems raised are actually less inspirational both in norms and social values. Nevertheless, it successfully presents a simulation of luxurious and comfortable life which may be most people's dream, mainly women's. In addition, at the reality show, The Kardashian family always performs optimally in fashion and lifestyle, including vacation spots to relax and unwind, i.e. Dubai, of which they consider an affordable vacation destination (their standard).

Kylie's personal Instagram contains different content from the family reality show she starred in though. Instead, she dwells on posting beautiful poses of herself displaying a grateful figure for her physical grace and face. This is done by Kylie to simultaneously 
promote the products of the business she built; it is currently a giant international business built by an individual, not a corporation. Pseudo structures are continuously displayed which seem to erase the impression that life is actually full of problems. Kylie's life always seems good and ideal (perfect) until she became pregnant at a very young age (19 years) with a rapper Travis Scott. This in the American view was a brave decision. Besides, Kylie's personal life is deliberately shown for public consumption and finally becomes a role model (influencer) especially in dressing (make up) style [10]. Endorse from a well-known clothing line company from Paris comes to use her body image as an image of design concept for displaying luxurious, glamourous and sexy impression.

\subsection{Visualization of Make Up Tutorials Pros-Cons on Instagram}

Before-after make up tutorial clearly displays simulacra framework as a representation of women's body and skin image. Moreover, the display of 'before and after' make up images has constructed the mind of Instagram netizens who see it to feel the phantasmagoria of artificial changes [11]. Beauty in make-up tutorials is an aesthetic definition for the pseudo image of a woman's face as to be falsely better or beautiful doesn't harm others [12]. The beauty displayed is apparently what everyone is willing to see. In addition, admiration and praise are a long-awaited desire form. Pseudo space factually appears in before-after make-up, yet the main problem is that every woman is mostly eager to be beautiful.

Opposition movement againsts the pseudo reality in beauty and make up has been carried out since five years ago by many women. The concept of their lateral thinking has led to an awareness that the desire to be beautiful is a denial and this makes women becomes individuals who are thirsty for compliments and are mentally unhealthy [13]. No make-up campaigns, one of which was popularized by Alicia Keys, a famous artist and celebgram, went viral and was followed by many women who were not willing to be too preoccupied with make up or dressing ritual to change to be different people and even different personalities. Doing an Anti mainstream with no make-up in public is definitely difficult for many women for it is still limited by the ideal construction in the society that looking beautiful is pleasant. No wearing make-up is bad since it is considered harassing themselves and other people around them. These are mainly needed by women working as front liners who directly interact with public, like cosmetics companies, flight attendants and banks. Female workers must attend special make up classes (given by the companies) and they are obliged to be proficient in make up [14].

Skin positivity rises following 'no make up campaign' as a competitor for 'make up tutorial'. Female figures appear with their posts showing their faces full of zits or pimples caused by hormonal factors and/or even face with severe and painful eczema (dermatitis). Acne is a huge commodity for cosmetic companies and people whose self-confidence problems due to general concept of beauty stating that a good appearance is even skin tone with no acne scars. If the pimples cannot disappear or heal, at least they can be covered to make face look better [15]. A positive attitude and acceptance toward a problematic facial condition is psychologically believed to accelerate the recovery process of the skin problem for it is mostly caused mainly by stress factor which disrupts body's immunity. Moreover, people reacts differently to stress. Some women may get fat and have acne. This is actually caused by wrong efforts toward stress. Satisfying consumption to pursue the meaning of 'satisfied' (fulfilling pseudo desires) and to dispel stress is usually distracted into unhealthy but delicious consumption for satisfying a $5 \mathrm{~cm}$ tongue [16]. 


\subsection{The Power of Face Make Up as Simulacra}

As long as simulacra helps women's lives to reconstruct skin image to look better which is initially opposed as a pseudo act form, it is, on the other hand, in the positive side able to switch to positivism which will improve women's self confidence. Therefore, the concept of pseudo hyper-reality becomes an instantaneous therapy for people whose professional obligations, for instance a model with vitiligo skin disorders and at the same time as a working mother. Their cognitive awareness is able to quickly switch and naturally change without experiencing bipolar disorder. In such cases they require a temporary simulacra therapy to live a normal life without interfering with general rules.

Make up is an aesthetically mild choice when viewed from temporary simulacra perspective rather than plastic surgery, silicone breast implants, liposuction, thread for beauty treatment, and skin whitening injection. The body temporarily accepts these pseudo conditions through inorganic treatments to be beautiful. Then it naturally returns to its original state as in resting position [17]. Varied surgical procedures which require strange material injection into the body are always risky. Cancer and genetic mutation cases occur due to long-term aesthetic surgical procedures which are harmful and detrimental to health and endanger life [18]. It is the right of every woman to be beautiful, yet it is necessary to consider ethics and reasonableness limit, fundamentally in establishing interaction through social media mainly on Instagram with its dominant visual commodity. Women's skin image in visual culture will perpetually remain attractive as a cultural arena since it persistently shows a variety of symptoms and new phenomena following their stimulating causes [19].

\section{CONCLUSION}

Make up tutorials phenomenon on Instagram euphoria is a small part of women response to celebrate, communicate, and seek attention. Thus, this is not a negative matter rather than commentary war and hoax. The best creations shown by women in make up tutorial, although still showing simulacra symptoms or simulacra syndrome, cannot be categorized into community disease. Instead, it is a solely derivative product from the space available on Instagram social media facility. Women who are initially infected with guilty feeling illness due to problematic face condition regain their power when exploring their abilities in make$u p$, recording, editing, and finally sharing them in their timeline. A critic, Baudrillard, will probably draw his statement back when he realizes that the progress of civilization and technology advancement has increasingly shown a tangible and decisive practice of simulacra theory. Make up tutorial has formed an ideology of beauty concept. Moreover, definition of 'beautiful by wearing make up' on some Instagram users is driven by a strong motivation to have a beautiful face appearance and as a means to gain recognition for the achievements on their physical change according to the ideal beauty guide in general public opinion.

\section{REFERENCE}

[1] Fitria, Herlinda. "Hipperealitas dalam Social Media (Studi Kasus Makan Cantik di Senopati Pada Masyarakat Perkotaan)", Informasi Kajian Ilmu Komunikasi, 45(2), 87100, 2015.

[2] Permanadeli, Risa. Dadi Wong Wadon: Representasi Sosial Perempuan Jawa di Era Modern. Yogyakarta: Pustaka Ifada, 2015. 
[3] Adegbola, Oluseyi et. al. "Using Instagram to Engage with (Potential) Consumers: A Study of Forbes Most Valuable Brands' Use of Instagram”, The Journal of Social Media in Society, 7(2), 232-251, 2018.

[4] Aziz, M. Imam. Galaksi Simulacra: Esai-esai Jean Baudrillard. Yogyakarta: Lkis, 2001.

[5] Barker, Chris. Cultural Studies: Teori dan Praktik. Bantul: Kreasi Wacana, 2018.

[6] Lipecky, F. "Simulacra in Science Fiction", Ars Aeterna Journal, 6(2), 1-11, 2014.

[7] Beller, Manfred et.al. Imagology: The Cultural Construction and Literary Representation of National Characters, A Critical Survey (Ed.). Amsterdam - New York: Rodopi, 2007.

[8] Achmad, Zainal Abidin et. al. "Etnografi Virtual sebagai Teknik Pengumpulan Data dan Metode Penelitian", The Journal of Society \& Media, 2(2), 130-145, 2018.

[9] Ida, Rachmah. Studi Media dan Kajian Budaya. Jakarta: Kencana, 2018.

[10] Deibert, Ronald. "The Road to Digital Unfreedom: Three Painful Thruts About Social Media", Journal of Democracy, 30(1), 25-39, 2019.

[11] Piliang, Yasraf Amir. Dunia yang Berlari: Dromologi, Implosi, Fantasmagoria. Yogyakarta: Aurora, 2017.

[12] Sumardjo, Jakob. Estetika Paradoks. Bandung: Kelir, 2014.

[13] Bono, Edward De. Berpikir Lateral. Jakarta, Penerbit Erlangga, 1991.

[14] Bordeau, Pierre. Arena Produksi Kultural Sebuah Kajian Sosiologi Budaya. Bantul: Kreasi Wacana, 2010.

[15] Cwynar-Horta, Jessica. "The Commodification of the Body Positive Movement on Instagram", STREAM Culture/Politics/Technology, 8(2), 36-56, 2016.

[16] Hogue, Jacqueline V. "The Effect of Active Social Media Engagement with Peers on Body Image in Young Women, Body Image, 28, 1-5, 2019.

[17] Javelanna, Genesis M. "Influences of media on Body Image Satisfaction among Adolescents", Asia Pacific Journal of Education, Arts and Sciences, 1(1), 95-101, 2014.

[18] Kakish, Heather et. al. "A Qualitative Analysis of Body Image on Social Media: Implications for Public Health Practice", 2(2), 1-6, 2018.

[19] Perloff, Richard M. "Social Media Effects on Young's Women Body Image Concerns: Theoretical Perspectives and an Agenda for Research", Feminist Forum Review Article, $1-15,2014$. 